\title{
An Affair of Honour
}

\section{Author(s): S. M.}

Source: Kerry Archaeological Magazine, Vol. 4, No. 18 (Apr., 1917), pp. 116-123

Stable URL: http://www.jstor.org/stable/30059757

\section{Accessed: 26-06-2016 03:06 UTC}

Your use of the JSTOR archive indicates your acceptance of the Terms \& Conditions of Use, available at

http://about.jstor.org/terms

JSTOR is a not-for-profit service that helps scholars, researchers, and students discover, use, and build upon a wide range of content in a trusted digital archive. We use information technology and tools to increase productivity and facilitate new forms of scholarship. For more information about JSTOR, please contact support@jstor.org. 

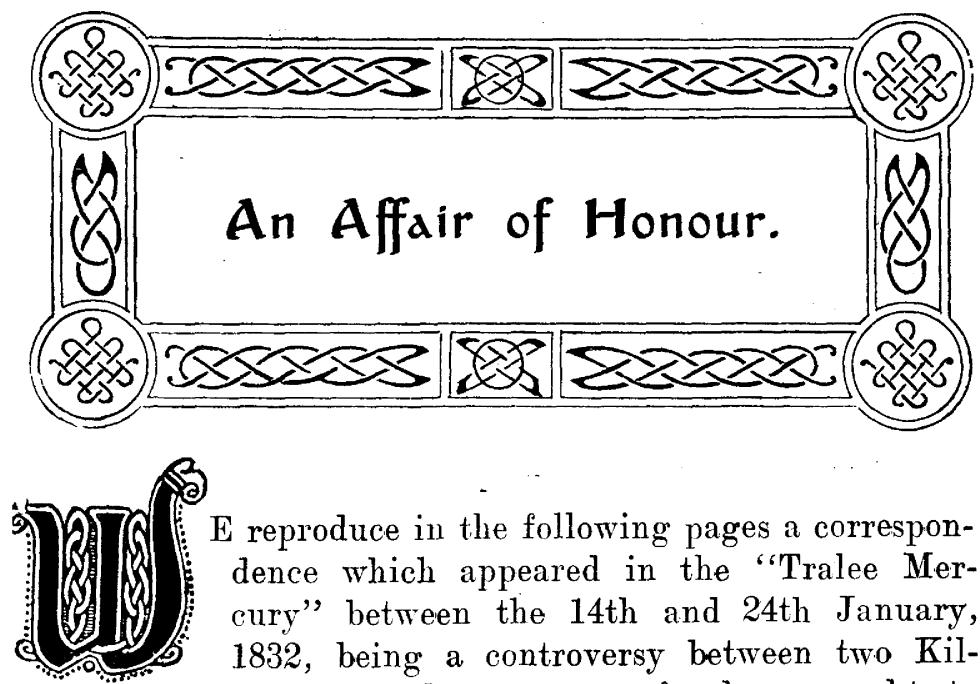

E reproduce in the following pages a correspondence which appeared in the "Tralee Mercury" between the 14th and 24th January, 1832, being a controversy between two Killarney gentlemen, one of whom sought to obtain from the other satisfaction for his wounded honour by the arbit. nent of single combat, which the latter for certain reasons refused to accord. Consequently the matter ended "in smoke" so far as those two gentlemen were concerned, though it led to a hostile meeting between two others who were incidentally drawn into the quarrel.

It would appear that duelling was very rife in Killarney at that period, and very often no doubt with less harmless results than those which followed from the paper war with which we are now concerned. Mr. King, in his "History of Kerry," has a note about the Killarney Club House of those days, which was situated next to the Protestant Church and nearly opposite the hotel then known as "Gorham's" and in recent years as the "Innisfallen." "Mine host," referring to certain gentlemen in blue frocks who were wont to lounge about the door of the club, used to say that "they spring up in these parts as thick as mushrooms; mightily idle gentlemen they are too; but it is better to let them alone; for, if one of them was to tread on your foot, he'd challenge you for crying 'oh!',"

A perusal of the correspondence may prove interesting, as illustrative of the manners and customs of a period not very remote from the present day, and as recording an incident which we understand led to a memorable split in the Killarney Society of that day. Though few descendants of 
any of the persons mentioned now survive, we deem it advisable to substitute other names for those mentioned. We start with a paragraph in the "Tralee Mercury" of the 11th January, 1832, from a Killarney correspondent giving a brief statement of what led to the quarrel. Then follow the letters from the parties themselves.

Killarney,

January 10th, 1832.

In consequence of an insult given in the billiard room yesterday morning by Mr. Arthur Hennegan to Mr. William D. Binger, Captain Jagoe waited, at an early hour this morning, on the former, with a hostile message which Mr. Henegan refused to accept, on the grounds that the gentleman whom he insulted was not "qualified." About one o'clock Mr. Binger cams into town, and having met Mr. Henegan opposite the Chamber of Commerce, he approached him and addressed him nearly as follows:- "You insulted me last night, and have refused to give me that satisfaction due from one gentleman to another; I now tell you that you are a c-d, a s g l, and $\mathrm{b}-\mathrm{d}$, and I treat you as such,' accompanying the last assertion with a blow of a horsewhip across the face. Previous to the blow Mr. Henegan stood with his hands under his cloak, and on being . Binger, but was stopped by his brother Mr. James Henegan. There are some other circumstances connected with this stage of the transaction, which for the present it may not be prudent to give publicity to. From Mr. Henegan's expressions, it is presumed he will seek redress, for the chastisement inflicted, in a Court of Law.

To the Editor of the "Tralee Mercury."

January 14th, 1832.

Sir-Having seen an article in the last "Tralee Mercury" from a Killarney correspondent headed "An Affair of Honour," in which it is reported that I insulted a Mr. Binger of Greenane, and afterwards when called upon, refused to give him a meeting or any apology, on the grounds of his not being "qualified," as the article alluded to calls it, I hasten to remove any injurious impressions to my prejudice, which I consider that insidious paragraph is calculated to leave on the mind of any person who may have read it, without being aware of the circumstances which have induced me to act as I have done. This can only be done for the present by detailing the facts as they occurred. Mr. Binger (as I will call him for convenience) was some time since proposed as a member of the Killarney Club. and was openly and avowedly black-beaned by several of the members, of whom I was one, as being a person with whom they refused to associate. Some time after this occurrence there was a meeting of the committee of the Club, called by Mr. John Mullaly, for the purpose of excluding all persons not authorised to come into to the billiard room, was requested to see that the rules were enforced; in consequence of which he gave general directions to the marker to that effect. Notwithstanding this, soon after Mr. Binger, to the surprise of everyone, came into the room in the company of Mr. Mullaly, who ust before was the first and foremost advocate for general exclusion. (t) afteruards came in by himself, when the marker pointed his attention to the resolution of the committee; and when asked by whose directions he did so, he said by orders of the Secretary.

Mr. Mullaly came into the billiard room in the evening, while 
my brother was playing, and said the conduct of the marker was highly improper. I replied that he was borne out by the rules, and by the order of the Secretary. Mr. Mullaly spoke a good deal more on the subject, when my brother observed that the billiard room was not a fit place for the discussion-that if any person thought it proper to impeach his conduct, he would account for it at a proper time and place. A short time after Mr. Mullaly said, "Mind, you have pledged yourself to be answerable for your conduct." I answered he had done so, but as he said, "it shall be at a proper time and place, and to a proper person, and if he does not, I will." Mr. Mullaly then left the room, saying as he went out, "I will go look for William Binger, and bring him in here, and see who will turn him out." He however failed to put his threat into execution.

The following morning Mr. Jagoe called upon me, and said he was directed to do so by Mr. Binger, who had been told by Mr. Mullaly that I said I should be accountable at a proper time and to a proper person, and wished to know whether by the latter expression I meant that Mr. Binger was not a proper person, that he required a disavowal or a meeting, or words to that effect. I said that in the course of my altercation with Mr. Mullaly I never mentioned Mr. Binger's name, I used the expression generally, that I thought anybody else may just as well make the same demand-that if $\mathrm{Mr}$. Binger thought fit to be captious, I did not consider myself bound to satisfy his scruples. When I was pressed by Mr. Jagoe to declare how I should act, if I thought $\mathrm{Mr}$. Binger had reason to call upon me, I said, "in that case I should certainly decline meeting him, as I did not consider him to be a gentleman, but, as I had pledged myself to $\mathrm{Mr}$. Mullaly, that I should be answerable to anyone I considered a proper person, I would not retract it, that I was ready to meet him, Mr. Jagoe, or any person with the character of a gentleman who thought proper to espouse Mr. Binger's supposed cause of quarrel. To this Mr. Jagoe made no reply, but that Mr. Binger would be obliged to resort to means that I might find disagreeable, and my answer was that he should take the consequences of that upon himself. I think it must appear evident to every person that even the friends of $\mathrm{Mr}$. Binger must have had a strong suspicion that his claim to be considered a "gentleman," was at least doubtful, when they pressed so hard to ascertain my opinion, who had never mentioned his name. Those judicious friends were, however, mistaken in their calculations, that I could be provoked to give him an opportunity of raising his character at my expense, by fighting a duel with him and then give him a spurious claim to be called a "Gentleman," as it is supposed to do.

These are four strong reasons why I do not consider him "qualified," as your correspondent has it:-

1stly.-Because I never considered him a "gentleman" and therefore black-beaned him.

2ndly.-Because he had the glaring indelicacy and want of common feeling to attempt to force himself into the company of persons who had repudiated his society.

3rdly.-Because he had the baseness to turn "common informer" against my friend and relative, Mr. Mullaly of Glenmoyle.

4thly.-And above all, because there are many of the most respectable persons in the County, both my friends and relations, whose acquaintance I should forfeit, if I did not sacrifice that strong momentary feeling, low as he is, to revenge the ruffian attack that he was instigated to make upon me.

If I met him, it must have been without a friend. 1 am not at present actuated by the smallest feeling of resentment towards him; 
as it is well-known that Providence has afflicted him with a malady such as must impair his intellect; and I should not appeal to law for redress, but that I consider a half-fool, as the most dangerous instrument in the hands of cunning persons who have adopted as their motto, and well know the application of the phrase- "Qui facit per alium facit per se," and thus shelter themselves from the consequences of their manoeuvres. I am aware that my private affairs can be of no consequence to the public, but the strong repugnance that I feel to being forced into print, particularly in such company, shall not prevent my removing any false impression coming before the public that may be likely to tarnish the character I wish to bear in society if left uncontradicted. I will be much obliged by your insertion of this letter. I regret from the treacherous nature of the former article that appeared in your paper a detailed account of the whole proceeding is necessary. I could not make it more condensed without the risk of rendering it perhaps unintelligible. Fully determined not to notice the affair again in print, I remain,

$$
\text { Your obedient Servant }
$$

$$
\text { ARTHUR HENEGAN. }
$$

To the Editor of the "Tralee Mercury."

$$
\text { "Killarney, 17th January, } 1832 .
$$

Sir-Having seen in your paper of the 14th inst., a letter signed "Arthur Henegan," I hesitated for some time as to the propriety of neplying to any observation coming from that person, after having so tamely borne, in all but words, the personal chastisement I inflicted on him; and I know I could not deprive him of that last privilege of cowards, "abuse and scurrility" which he is so well aware he may now indulge with impunity. But, however, as that letter may have created a mistaken impression on the minds of persons unacquainted with us both, I will enter a little into particulars.

I will commence by enquiring upon what this person grounds his aristocratic pretensions in refusing to meet me as a gentleman? really am at a loss to know whether he rests them on superiority of family, fortune, or conduct; but we can consider all, and the public will judge with whom the superiority remains, if there be any.

the of us has any great pretensions to fortune or station. We both rank as middlemen on the estate of the Earl of Kenmare; our fathers were similarly circumstanced, having no other means but what they thus derived, and I believe their profits were nearly equal. They moved in the same circle, were received in the same society, and were both members of the Volunteer Corps then so prevalent in Ireland. I have heard it said, and I believe it will not be renied, that my father had the good fortune to obtain the estom and to perform his official duties with that forbearance and humanity so becoming in a solder. he never converted the arms, with which he was entrusted by his King and his country, into the weapons of in family, which we are told (and we have daily instances of it) descends even to the third and fourth generation. I can, with equal truth, say of that lamented father, that he conducted himself with the same amiability in all the relations of private life : he was a dutiful and obedient son, a kind and careful father, and an "attached and affectionate husband," thus benefitting his family by an example, which I trust they have and will endeavour to pursue. Having thus disposed of the pretensions of the father, I next come to those of the sons, and I will in the first place tell you what I am not: I am not the intemperate brawler of the gambling table, equally offensive by his blasphemy and rudeness at night, and cringing cowardice in the morning. I am not at one moment meriting and receiving personal chastisement, 
and in the next, sheltering my want of spirit under a pretended superiority, or some equally vague excuse ; for, be it known, this is not the first time this hero has kissed the rod. He was treated meek under the infliction. How he then evaded the consequences. meek under the infliction. How he then evaded the consequences. for no redress as a rentleman. But perhaps, after all this unforfor no redress as a gentere young man is not so much to blame, he had not the benefit of good example, and it is said the curse descends; but really the patrician pretensions of this "gentleman," whose annual income does patrician pretensions of this "gentleman," whose annual income does It is quite a year, to superiority in any respect are too absurd. It is quite clear that I am countenanced and associated with by persons fully the equals, if not the superiors, of those who would fain uphold this person's "dignity." I need only instance the fact of a Captain in the Army being the person through whom 1 communicated with him, and I might add the intimacy I enjoy with another officer of this town, equally remarkable for his gentlemanly demeanour and his high sense of honour, but to whom this person $t$ proper to allude in terms which he will not of course are impudent.

It is evident that if $I$ did not rank as a gentleman, or if I had by my conduct for a moment forfeited my claim to that station, I should not be so supported and countenanced, as it is well known Military men are better judges and more sensitive on these points than most other persons. But 1 will leave general assertions and come to particulars. This person assigns as his first reason for not meeting me "that I was black-beaned in the Killarney. Club." Such a circumstance would be a bad criterion by which to judge a person's claim to the rank of a gentloman, where any independent individual can with such safety form a party to carry his malignity into effect, and where one black bean in seven excludes. It is well known there are daily instances of persons of the highest respectability and patriotic feeling being black-beaned by parties in clubs of this description, without any forfeiture of character or relinquishment of station.

But we will sift this matter further and see how it stands. I deny that I was black-beaned by any one person "because I was not considered a gentleman"; but I assert I was black-beaned by a party formed against me by Mr. Gerrge Mullaly of Glenmoyle, avowedly and for no other reason than that I happened to be the cousin-german of Mr. William Binger, of Sunnyside, with whom he, at one time, had a dispute, and which Mr. Binger endeavoured to have settled in the way that is usual among gentlemen, when amicable interference proves of no avail-namely, by a hostile meeting, which it must b admittedly was conducted honourably on his part; and I really can conceive no other reason for Mr. Mullaly's malignant perseverance in his rancorous hostility, not only to that gentleman himself, but, a it would appear, to his whole family and connections, except the fact of its having proved fatal to him.

I have, I think, disposed of this person's first objection, and I now come to the second, namely, "that, by going into the billiard room I forced myself into the company of those who before repudiated my society." This is evidently but a repetition of the black-beaning objection. It is true I did go for a moment into the billiard room, whilst a gentleman was ascertaining whether a person I wanted to see was in the reading room, and I did so withont apprehension, for the exclusive rule to which $\mathrm{Mr}$. Henegan alludes was in no instance acted on, and particularly, as there was then in the room the person whose conduct induced that rule to be called for. This person how ever, was left unmolested, whilst I was treated with a rudeness and 
harshness in no other instance exercised, by having, and I must indeed say unfortunately, given Mr. James Henegan (the volunteer secretunity of converting his little brief authority into an engine of party, in a manner for which he may rest assured of my inclination to have called him to account, but that it was the opinion of my friends he was protected by the rule to the harsh operation of which I had incautiously subjected myself.

I now come to the third objection, viz: "That I had turned common informer against Mr. Henegan's friend and relative, Mr. common informer against Mr. Henegan's friend and relative, Mr. in a moment of natural irritation, at this gentleman's so causelessly in a moment of natural irritation, at this gentleman's so causelessly acquaint the Government of the manner in which he had been acquaint the Government of the manner in which he had been tenant of Militia when he was not entitled to do so. 1 also threat-

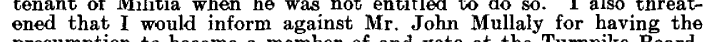
presumption to become a member of and vote at the Turnpike Board, presumption to become a member of and , vote at the Turnpike Board,
for which he could by no means "qualify" (to use a favourite expresfor which he could by no means "qualify" (to use a favourite expres-
sion of my opponents). I however, carried neither threat into effect, though I assert I had and have the power of doing so.

I will nevertheless leave Mr. George Mullaly to receive his comI will nevertheless leave Mr. George Mullaly to receive his com-
pensation in his usual manner (he will understand the phrase) undisturbed by me- but I rather think the functions of the ex-
member of the Turnpike Board have ceased owing to the threat that was held out.

s held out. There are other observations of this person which I pass over with
the contempt they merit. The feeling that could dictate them will, I am sure, be only appreciated; but I thank God they do not apply $\mathrm{m}$ as much superior to him in vigour of mind and body man.-I am, Sir, your obedient servant,

\section{WILLIAM D. BINGER.}

P.S.- The qualification of a Trustee is $£ 300$ a year, a third of which he has not. A militia officer, to entitle himself to receive halfpay or compensation, pay or compensation, swears four times a year that he is

\section{To the Editor of the "Mercury"}

"Killarney, January 24th, 1832.

Sir-Though, in general, not subject to be easily surprised, I must confess I was totally unprepared for tit unblushing and untiring reiteration of falsehoods that have appeared in a letter signed "William D. Binger," but of which Mr. James Binger has since avowed hiriself an "author," and of course immediately received, in part at least the punishment his conduct, so richly merited.

Though I never had the bad taste to allude to the gentleman's family or connections, he takes an opportunity of eulogising them, by comparison with mine. It was not in consequence of his "birth," whatever it may be that I refused to meet Mr. William D. Binger but on account of his own conduct, particularly his being a convicted and admitted "informer" I said so on the spot, the moment after he assanlted me. My brother having "met" his, is sufficient prouf of this; and though it is said, in the letter of many authors, that "he only went into the billiard room to wait for his friend", his having afterwards 'forced himself' with a crowd of his supporters into the supper room at night, in such a manner as to compel the peac on wanted) that I, in my former letter, have properly estimated his 
character. It is said that an exception was made with regard to the rule of exclusion in favour of another person, meaning $\mathrm{Mr}$. Frederick Lucas. This is not true-that gentleman has been an honorary member these 20 years. However, these and all the minor fabrications I pass by as quite unworthy of public refutation-they would occupy more than half your columns, and they are too well known to be false, at least in this part of the country, to require it.

But there are two circumstances alluded to which I feel myself bound to notice the particulars are carefully avoided, as they would, in themselves, give a direct contradiction to the assertions that are made respecting them, and so save me the annoyance of being obliged to forego my original determination of not appearing again in print.

The first insinuation is, "that my father converted the arms entrusted to him by his country into the weapons of the assassin." This occurrence is so long gone by that probably few will understand the allusion. It is this: At the time the country was so disturbed as to render the services of the Foresters necessary: there was a prisoner taken, and my father was directed with a small party to convey him to the gaol of Tralee. On the way he got information that a rescue was intended, which proved correct, as he was met at Batterfield by a large party of the country people, who demanded the prisoner. He, of course, refused to comply; and wishing to avoid bloodshed he produced the warrant for committal and offered to go with them to the house of Mr. James Mahony of Batterfield, who was the nearest magistrate, and if he would take the responsibility on himself, my father was willing to give up the prisoner to him. This they declined doing, and left him for the time; however, when they arrived at the Tralee side of the mountain, at a pass called Farmers' Bridge, they were suddenly attacked by an increased party, who would have murdered my father and his small party but for his promptitude and determination in shooting their leader, who made a blow at his head with a sword, which he avoided. He executed his orders, and lodged the prisoner in gaol. There was no prosecution attempted, but, at the following assizes, he and $\mathbf{M r}$. Bartholomew Shea, who accompanied him, demanded a trial-the Bills of Indictment were thrown out, and they received public thanks from the judge for having properly performed their duty.

The other charge is: "that I was first flogged and then obliged to kiss the rod, by the late Mr. B. Jagoe." The facts are these: A dispute arose, from a misconception, between that gentleman and myself, in which I conceived myself injured, and therefore sent him a message by Mr. O'Rourke of Gowlane, which he declined, giving as reasons for so doing that I was under age at the time, and that he was a man of large family. This comparatively is so recent an affair that my assertion can, if necessary, be corroborated by Mr. O'Rourke and many others.

I regret, Mr. Editor, that the aspersions attempted to be thrown on my father's memory and my character render it necessary for me to request you will have the kindness to publish this letter.

I remain, yours \&c.,

\section{ARTHƯR HENEGAN.}

To the Editor.

Sir-Mr. James Binger, the present avowed author of a letter signed "William D. Binger," which appeared in your paper of Wednesday last reflecting on the character of my brother, Mr. John Mullaly and myself, having received from the former well-merited chastisement, I should rest satisfied with that termination of the affair if your paper was only to be read by those who know the parties concerned. As it is, I shall merely state that I defy Mr. 
James Binger to prove his assertions, and I fling back with supreme contempt his false and caluminous accusations.

$$
\text { I have, \&c., }
$$

Glenmoyle, 23rd January, 1832.

(From "Tralee Mercury" of February, 1832).

AFFAIR OF HONOUR.

On Monciay last George Mullaly, Esq., and James Binger, Esq., the fcrmer attended by J. lateward of Millstreet in the Co. of Cork, Esq., and the latter by Walter Handyside of Kenmare, Esq., met at the Park. near Killarney, where, after an exchange of shots, the police having appeared and arrested Mr. Mullaly, and the mob having violently assauited some of $\mathrm{Mr}$. Binger's friends, the affair terminated. Mr. James Binger escaped the arrest of the police.

In the same issue appears a further letter, dated 29th January, 1832, from Mr. William D. Binger, with reference to Mr. Henegan's of the 24th January, of a vituperative nature, and accusing him of cowardice, and pointing out some discrepancies. So the affair apparently ended between those two persons so far as the paper reports go to show.

S. M.

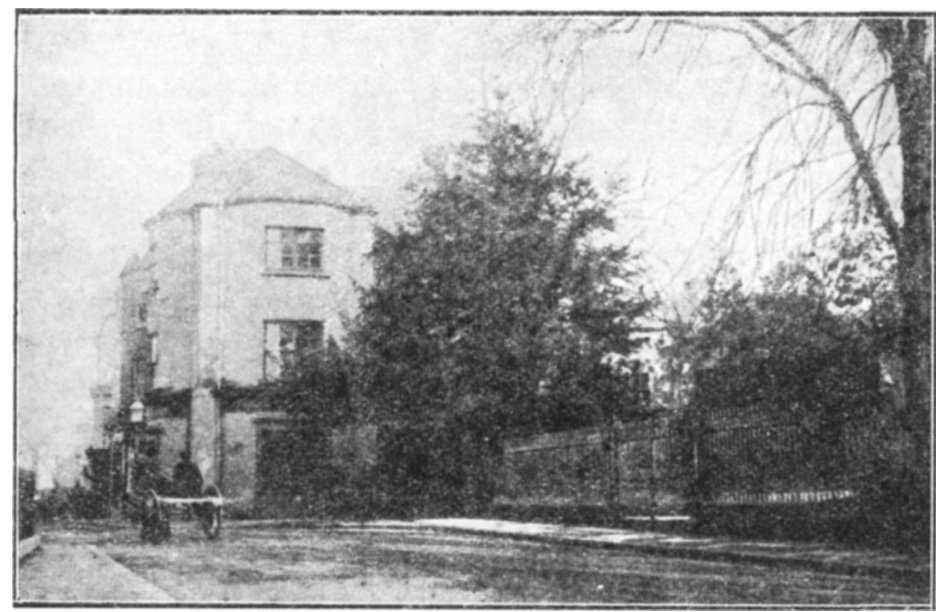

THE OLD CLUB HOUSE IN KILLARNEY. 